\title{
nature
}

25 April 2002 Volume 416 Issue no 6883

\section{France sleepwalks into chaos}

The success of the extreme right in the first round of the French presidential elections serves as a warning to all responsible citizens - scientists included - not to disengage from the political process.

A cartoon on the front of Le Monde said it all: an airliner with the face of extreme right-winger Jean-Marie Le Pen crashing into twin towers labelled Jacques Chirac, the centre-right French president, and Lionel Jospin, the socialist prime minister. That the latter two men would defeat the 14 other candidates in the first round of France's presidential elections was regarded as a foregone conclusion. The news that Le Pen will run head-to-head against Chirac in the second round has rocked French society to the core.

Le Pen's strong showing does not mean that France is seriously flirting with government by the extreme right: the combined vote of the mainstream right and left will keep Le Pen from office, and hand victory to Chirac. Rather, the first-round results are the manifestation of a widening gap between the French people and its ruling political class. Turned off by a campaign in which neither mainstream candidate engaged in a meaningful debate on such issues as France's future in Europe, many citizens registered a protest vote for a minority candidate, or simply stayed at home.

The shock of finding Le Pen's name on the ballot paper for the second round presents both a danger and an opportunity. There is a risk that protests against Le Pen will spill over into violence, playing into the extremists' hands. More optimistically, the shock wave could shake France out of its slumber, and displace the uninspiring faces that have dominated the French political scene for three decades. The humiliated Jospin has already said that he will quit politics.

Needless to say, policies on science and innovation were largely absent from the electoral debate. Yet they are key to the economic and intellectual future of any modern country - and France's staid, bureaucratic and inefficient research system is in urgent need of attention. Today's scientific enterprise needs a flexible, highly mobile workforce. The French system, in which most scientists are civil servants who can spend their entire careers attached to one research unit, is ill-equipped to provide this. French science needs a postdoc system to encourage mobility between research groups; universities need a shake-up to encourage more productive interactions with the public research laboratories that they host, plus an injection of funds to free scientists from long teaching hours; and research labs need to be lifted from the treacle-like bureaucracy of French public administration.

Once Le Pen has been seen off, French researchers have everything to gain from re-engaging with the political process and putting science back on the agenda. Responsibility for science policy lies not with the president, but with the prime minister's government, and the parliamentary elections that will determine who forms that government will take place in June.

Recent governments of left and right have not served French science well. In the mid-1990s, the right slashed budgets. And while the socialists restored funding, they have let the underlying problems of French science rumble on. Jospin's first science minister, Claude Allègre, realized the need for reform, but his undiplomatic style and poorly thought-through plans delivered little beyond a series of rows with the organizations he was seeking to change. His successor, Roger-Gérard Schwartzenberg, has avoided such conflicts. But that is about the sum of his achievement.

France deserves better. The country's scientists should now play their part in putting in place a government that is up to the task of leading one of Europe's great nations in the twenty-first century.

\section{Maintaining the climate consensus}

\section{The election of a new chair for the Intergovernmental Panel on Climate Change has left wounds that the victor must heal.}

$\mathrm{T}$ he circumstances under which the Indian energy economist Rajendra Pachauri won the chair of the Intergovernmental Panel on Climate Change (IPCC) are not auspicious. As soon as he was elected, Pachauri was denounced in The New York Times by former US vice-president Al Gore as "the 'let's drag our feet' candidate". For the new head of the body that is supposed to advise the world's governments on the complexities of global warming, things can only get better.

Previously, consensus had emerged on the IPCC's leadership. But an orchestrated campaign by the US administration and the fossilfuel lobby forced the vote on 19 April in which Pachauri defeated the incumbent, atmospheric scientist Robert Watson, by 76 votes to 49 .

Climate researchers appreciated the way in which Watson defended their findings from politically motivated attacks during his tenure. Many will now be wary of Pachauri, who appears to have tarnished his reputation by collaborating with those whose objective was to ditch Watson.

But Pachauri has the credentials to make a go of his main role, which is to build confidence in the impartiality of the IPCC's advice.
His expertise in energy policy and economic development is central to the panel's mission, and his involvement with the oil industry - he is a director of the Indian Oil Corporation - may help to establish more credibility with business interests. And after two leaders from rich nations (Watson's predecessor, meteorologist Bert Bolin, was Swedish) it is good for the IPCC to be run by someone from a developing country.

Pachauri will have to establish his credibility with scientists quickly, however. Researchers give their time to the panel for free, and they need to feel that the chair will back them up. Pachauri must reassure the IPCC's rank and file that he will fend off any attempts to bully the panel into watering down its findings.

He should also be thinking about negotiations on greenhouse-gas emission targets under the Kyoto Protocol from 2013. Talks begin in 2005, two years before the IPCC's next assessment is due. An interim report from the IPCC would inform the negotiations about the latest science. Such a document can only be requested by the panel's member states, but Pachauri should make it clear that his teams are ready and willing to provide it. 